\title{
Julian Kałowski
}

\section{Czas trwania nowicjatu}

Prawo Kanoniczne : kwartalnik prawno-historyczny 31/1-2, 111-126

1988

Artykuł został zdigitalizowany i opracowany do udostępnienia w internecie przez Muzeum Historii Polski w ramach prac podejmowanych na rzecz zapewnienia otwartego, powszechnego i trwałego dostępu do polskiego dorobku naukowego i kulturalnego. Artykuł jest umieszczony w kolekcji cyfrowej bazhum.muzhp.pl, gromadzącej zawartość polskich czasopism humanistycznych i społecznych.

Tekst jest udostępniony do wykorzystania w ramach dozwolonego użytku. 


\section{CZAS TRWANIA NOWICJATU}

Przygotowanie do praktykowania rad ewangelicznych zawsze uważano za jedno $\mathrm{z}$ najważniejszych zadań każdej formy instytutów życia konsekrowanego. $Z$ tej przeto racji od momentu pojawienia się $\mathrm{w}$ Kościele zorganizowanych społ̌eczności życia zakonnego ustawicznie troszczono się nie tyllko o dokładne poinformowanie kandydatów o nowego rodzaju obowiązkach, ale starano się także zorientować, czy owi kandydaci posiadają wystarczające przymioty oraz czy będą oni zdolni sprostać stawianym im wymaganiom.

Ponieważ zaś okres poprzedzający zarówno czasowa, jak i definitywną inkorporacje do instytutu nie mógł trwać zbyt długo, dlatego stało się koniecznością określenie tej kwestii najpierw w praktyce, a później w ustawach poszczególnych instytutów oraz powszechnym prawie kościelnym. Również i obecnie obowiązujący Kodeks Prawa Kanonicznego, promulgowany przez Jana Pawła II w 1983 r., omawia to zagadnienie (kanony 648 i 649).

Ze względu na ustawiczne zmiany $w$ zakresie czasu trwania nowicjatu wydaje się rzeczą bardzo pożyteczną przeanalizowanie tego problemu i poświęcenie $m u$ niniejszego artykułu. Trzeba również zaznaczyć, że ponieważ $\mathrm{w}$ historii instytutów zakonnych różnie podchodzono do czasu trwania nowicjatu, nieobecności $w$ nim oraz przerwania go, stąd rodzi się konieczność przynajınniej krótkiego scharakteryzowania wymienionych wyżej problemów.

\section{I}

Już u pierwszych twórców zorganizowanych form życia zakonnego, do których zwykło się zaliczać św. Pachomiusza (292-346), a na Zachodzie św. Benedykta (480-543), oraz i wielu innych zakonodawców spotykamy się z okresem wstępnej próby poprzedzającym definitywne wiączenie do wspólnoty 1 . Należy jednak zwrócić uwagę na fakt, że chociaż pierwsi zakonodawcy wprowadzili „nowicjat”, to jednak na ogół 2 nie określali oni czasokre-

1 Reguła św. Pachomiusza, c. 49, Starożytne reguły zakonne, przekład zbiorowy, Warszawa 1980, s. 44; Reguza św. Benedykta, c. 58, s. $224-225$; R. B a k a la r c z y k, De novitiatu, Washingtion 1927, s. $13-$ $14,21-26$.

2 Reguta św. Benedykta, c. 58. 
su próby, który uzależniali od przełożonego przyjmującego kandydata 3 . Dopiero św. Benedykt zarządził $w$ zredagowanej przez siebie regule, by nowo zgłaszajacy się do zakonu kandydat został przyjęty do wspólnoty po odbyciu dwunastomiesięcznej próby: „Tak więc, gdy ktoś przyjdzie i będzie kołatać wytrwale, gdy okaże się po czterech lub pięciu dniach, że potrafi znosić cierpliwie wyrządzane mu przykrości i utrudnienia wstąpienia, a prośbę swoją ciągle powtarza, wówczas należy mu pozwolić na wstąpienie. A niech przez kilka dni pozostanie jeszcze w celi gości. Później zaś zamieszka w celi nowicjuszy, gdzie mają oni rozmyślać, a także jadać i sypiać. Przydzieli się im mnicha starszego, takiego, który umie pozyskiwać dusze, by ich bardzo uważnie obserwowal. Trzeba badać troskliwie, czy nowicjusz prawdziwie Boga szuka, czy jest gorliwy w służbie Bożej, w posłuszeństwie, w znoszeniu upokorzeń. Należy mu $z$ góry przedstawić wszystkie rzeczy trudne i przykre, przez które musimy przejść, aby dojść do Boga.

Jeżeli nowicjusz zobowiąże się do wytrwania w stałości, po upływie dwóch miesięcy zostanie mu odczytana ta Reguła od początku do końca. I wówczas powiedzą-mu: Oto prawo, pod którym chcesz służyć. Jeśli umiesz je zachować, wstąp, jeśli nie możesz, odejdź wolny... I po upływie sześciu miesięcy zostanie mu odczytana Reguła, aby wiedział, na co się decyduje. A jeśli nadal nie zmieni zdania, po czterech miesiącach ponownie zostanie mu odczytana ta sama Reguła.

A jeśli po dojrzałej rozwadze obieca, że będzie wszystkiego przestrzegał i spelniał wszelkie polecenia, wtedy dopiero należy go przyjąć do wspólnoty. Powinien jednak wiedzieć, że na mocy prawa, jakim jest Reguła, nie wolno mu od tego dnia opuszczać klasztoru, nie wolno mu strząsnąć z karku jarzma Reguły, które tak długo rozważając mógł łatwo albo odrzucić, albo przyjąć.

Ten, który ma być przyjęty, w oratorium, w obecnośsci wszystkich złoży przyrzeczenie stałości miejsca, życia w cnotach monastycznych i posłuszeństwa przed Bogiem i Jego świętymi, aby wiedział, że jeśli kiedyłolwiek inaczej postąpi, zostanie potępiony przez Tego, którego szydzi" 4.

$Z$ przytoczonego powyżej tekstu Reguły wynika, że św. Benedykt $z$ Nursji przepisał rok próby, ustanowił formalny nowicjat, w którym nowicjusze pouczeni byli o obowiązkach życia zakonnego oraz poddawani różnego rodzaju doświadczeniom ${ }^{5}$.

$3 \mathrm{~V}$. Hermans, De novitiatu in Ordine Benedictino-Cisterciensi et in iure communi usque ad annum 1335, Analecta Sacri Ordinis Cistereiensis, fasc. $1-4$, Romae 1949 , s. 89.

4 Reguza św. Benedykta, c. 58.

- Reguza sw. Benedykta, c. 58; R. B ak a Iarczy k, s. 24. 
Należy równiė̇ zaznaczyć, że już od czasów cesarza Konstantyna chrześcijańscy panujący uważali się za opiekunów Kościoła i jego sprawy normowali swoimi ustawami. Czynil tak cesarz Teodozjusz 6 oraz Justynian w Kodeksie, a przede wszystkim W Nowelach 7. Ten ostatni mówił, że dopiero po trzech latach wolno dopuścić kandydatów do obłóczyn, co było równoznaczne ze złożeniem profesji zakonnej i definitywnym wcieleniem do instytutu 8 :

Papiez, św. Grzegorz Wielki (590-604), jako jeden z pierwszych zarządził, by włączenie do zakonu zostało poprzedzone dwuletnią próbą, a dla żołnierzy po odbyciu słuzby wojskowej trzyletnią 9 .

W XIII wieku następuje rozkwit życia zakonnego. Najbardziej znane, a następnie i rozpowszechnione instytuty to dominikanie, czyli zakon kaznodziejski, oraz zakon założony przez św. Franciszka z Asyżu (bracia miejsi). Prawodawstwo tych instytutów zobowiązywało, by zgłaszających się kandydatów dokładnie egzaminować na okoliczność stanu wolnego oraz znajomości prawd wiary 10.

Trzeba podkreślić również fakt o dużym znaczeniu, który później przeszedl do prawodawstwa powszechnego, że w zakonie franciszkańskim przyjmowanie do instytutu zastrzeżone zostało wyłạcznie dla przełożonych prowincjalnych 11. Papież zaś Honoriusz III (1216-1227) polecił franciszkanom, by $w$ ich zakonie dopusz-

${ }^{6}$ Por. Cod. Theod. III, IX, XVI.

7 Por. Nov. V-VII oraz inne; A. M. Stickler, Historia Iuris Canonici Latini. I. Historia fontium, Augustae Taurinorum 1950, s. 71.

8 Nov. V. 1: "Hine autem nobis etiam de singulis monachis cogitandum est, quo conveniat fieri modo, et utrum liberos solum, an etiam forte servos, eo quod omnes similiter divina susceperit gratia, praedicans palam, quila, quantum ad Dei cultum, non est masculus neque foemina, neque liber, neque servus: omnes enim in Christo unam mercedem percipere. Sancimus ergo, sacras sequentes regulas, eos qui singularem conversationem profitentur, non prompte mox a reverendissimis Praesulibus venerabilium monasteriorum habitum percipere monachalem: sed per triennium totum (sive liberi forte sint, sive servi) tolerare nondum monachicum habitum promorentes: sed tonsura, et veste eorum, qui laici vocantur, uti, et manere divina addiscentes eloquia: et reverendissimos eorum Abbates requirere eos, sive liberi sint, sive servi, et unde eis desiderium vitae singularis accesserit: et discentes ab eis, quia nulla maligna occasio ad hoc eos adduxit, habere eos inter eos, qui adhuc docentur, atque monentur: et experimento percipere eorum tolerantiam et honestatem: non enim facilis est vitae mutatio, sed cum animae sit labore.

\$ 1. Et dum triennio toto ita permanserint, optimos semetipsos et tolerabiles aliis monachis et Praesuli demonstrantes, hos monachicam promereri vestem atque tonsuram...".

9 R. Bakalarczyk, s. 31 ; V. Hermans, s. $88-89$.

10 R. Bakalarczyk, s. 34 .

11 Tamże. 
czano do złożenia pierwszych ślubów nie wrześniej jak po ukończeniu rocznej próby 12.

W miarę rozwoju życia zakonnego i prawodawstwa kościelnego papieże i sobory powszechne wydawali liczne. zarządzenia odnoszące się do czasu trwania nowicjatu oraz jego ważności. I tak papież Aleksander IV (1254-1261) zobowiązał kompetentnych przełożonych zakonu braci mniejszych i dominikanów pod ślubem posłuszeństwa i karą popadnięcia $w$ ekskomunikę, by nie dopuszczali oni kandydatów do złożenia pierwszych ślubów przed ukonczeniem rocznego nowicjatu ${ }^{13}$. W tymże samym dekrecie papież Aleksander IV postanowil również, że sluby zakonne tych, którzy by je złożyli przed ukończeniem rocznego nowicjatu, na mocy samego prawa są nieważne i nie powcdują żadnych skutków prawnych, a zatem nie włączają do zakonu. Wszyscy zaś przełożeni przyjmujący taką profesję pozbawieni zostaja prawa przyjmowania nowych kandydatów oraz stosownie do winy będzie im można nałożyć inne cięższe kary kanoniczne ${ }^{14 .}$

12 Tamże i cytowana literatura.

13 $\mathrm{VI}^{\circ}$, III, 14, 2: "Non sulum (In favorem conversi, sed etiam monasterii, probationis tempus a sanctis patribus est indultum, ut ille asperitates illius, et istud mores jllius valeat experiri. In regula quoque B. Benedicti praecipitur, ut ad conversionem noviter venientibus non facilis tribuatur ingressus, sed, sicut docet Apostolus, an sit ex Deo spiritus comprobetur, et dura et aspera, per quae itur ad Dominum, exponantur. Postea in eodem regula subiungitur, ut dicatur... Insuper felicis recordationis Gregorius papa praedecessor noster statulit, ut positi in probatione novitii ante susceptum religionis habitum, qui dari profitentibus consuevit, seu ante professionem emissam, ad statum pnistinum redire possint libere infra annum...) Licet zelum animarum habentes eas lucravi Domino sollicite cupiatis, quia tamen decet et expedit, ut conscientiae puritati non desit iudicium rationis, ne, unde spiritualis profectus quaeritur, salutis dispendium. Subsequatur: vobis de fratrum nostrorum consilio in virtute obedientiae et sub poena excommunicationis auctonitate praesentium districtius inhibemus, ne ante annum probationis elapsum, qui est maxime in subsidium fragilitatis humanae regulariter institutus, quemquam ad professionem vestri ordinis seu renunciationem in saeculo faciendam recipere, nec constitutum infra huiusmodi annum aliquatenus impedire, quo minus infra ipsum ad aliam religionem quam maluerit, transeat, vel nisi, maiior tamen quatuordecim annis existens, professus sit tacite vel expresse, aut evidenter constet, illum viitam voluisse mutare, quod tamen non praesumitur, nisi clara probatione vel competentibus iudicilis ostendatur, omnino ad saeculum redeat, sicut de sua voluntate processerit, praesumatis. Quodsi forte contra hanc nostram prohibitionem quemquam recipere praesumpseritis: decernimus, eum, quif taliter receptus fuerit, nullatenus vestro esse ordini alligatum vosque a receptione quorumlibet ad professionem eiusdem ordinis fore ipso facto suspensos, et insuper poenae subiliciendos, quae fratribus ipsius ordi-, nis pro culpis infligi gravioriibus consuevit". 


\section{II}

Ponieważ $w$ sprawie czasokresu trwania nowicjatu pomimo licznych aktów prawnych, o których już była mowa, wytworzyła się różna praktyka, dlatego Sobór Trydencki (1545-1563), zajmując się wśród wielu problemów natury doktrynalno-dyscyplinarnej również reformą życia zakonnego, na sesji 25 wydał dekret De regularibus et monialibus 15 . W dekrecie tym w sprawie nowicjatu zarządzono:

1) Zarówno $w$ zakonach męskich, jak $\mathrm{i}$ żeńskich nie można dopuścić do złożenia pierwszych ślubów przed ukończeniem szesnastego roku życia 16 .

2) Do złożenia pierwszych ślubów zakonnych mogą być dopuszczeni tylko ci nowicjusze, którzy po otrzymaniu habitu odbyli jednoroczną próbę ${ }^{17}$.

3) Sluby złożone przed ukończeniem nowicjatu trwajacego jeden rok są nieważne i nie powodują żadnych skutków prawnych 18 .

4) Po zakończeniu rocznego nowicjatu kompetentni przełożeni, o ile nowicjusz spełnia wymagane warunki i zostal uznany za zdolnego do podjęcia życia zakonnego, powinien być dopuszczony do złożenia ślubów, w przeciwnym wypadku należy go usunąć z zakonu 19.

W XIX i XX wieku, po przezwyciężeniu różnych problemów natury prawnej oraz dla zaradzenia aktualnym potrzebom Kościoła, nastąiła jakby „eksplozja” różnych zgromadzeń zakonnych o slubach prostych. Z tej przeto racji Stolica Apostolska, chcąc instytuty te zrównać $w$ prawach i obowiązkach z zakonami o ślubach uroczystych, promulgowała liczne dokumenty, z których dwa najważniejsze to konstytucja apostolska Conditae a Christo, wydana dnia 8 XII 1900 roku przez papieża Leona XIII 20 oraz

\footnotetext{
14 Tami̇e.

15 Conc. Trid. sess. XXV, de regularibus et monialibus, c. XV, Conciliorum oecumenicorum decreta curantibus J. A I be rig o, J. A. D o ssetti, P. Joannou, C. Leonardi, P. Prodi, consultante, H. Jedin, ed. III, Bologna 1973, s. 781.

16 Tamże: „In quacumque religione, tam virorum quam mulierum, professio non fiat ante sextum decimum annum expletum, nec qui minari tempore, quam per annum post susceptum habitum, in probatione steterit, ad professionem admittatur. Professio autem antea facta sit nulla nullamque inducat obligationem ad alicuius regulae vel religionis vel ardinis observationem aut ad alios quoscumque effectus".

17 Tamże.

18 Tamże.

19 Tamże, c. XVI: „Finito tempore novitliatus, superiores novitios, quos habiles invenerint, ad profitendum admittant, aut e monasterio eos eiliciant".

${ }^{20}$ Leon XII, Const. ap. Conditae a Christo, die 8 decembris 19.00,
} 
Normy ogloszone przez Kongregację Biskupów i Zakonników 28 VI 1901 roku, według których Kongregacja zwykła postępować przy zatwierdzaniu nowych instytutów o ślubach prostych 21 .

W sprawie czasu trwania nowicjatu Normy postanowiły:

1) „Stosownie do odmiennej natury różnych zgromadzeń nowicjat trwa niekiedy dwa lata, ale jeden cały i nieprzerwany rok jest wymagany koniecznie dla każdego zgromadzenia do ważności profesji" 22.

2) „Czas trwania nowicjatu określony konstytucjami nie może być zmniejszony przez przełożonych. Dla ważnych jednak przyczyn i za zgoda rady generalnej może być przedlużony w poszczególnych przypadkach, lecz nie ponad trzy miesiace" 23.

Z przytoczonych powyżej tekstów Norm wynika, że:

1) Chociaż w niektórych instytutach zakonnych nowicjat może trwać dwa lata, to tylko rok nieprzerwany należy do jego ważności.

2) Nie może on być skrócony przez przelożonych. Jedynie w uzasadnionych wypadkach i przy zaistnieniu ważnych powodów istnieje możliwość przedłużenia go o trzy miesiące, ale może to uczynić tylko przelożony generalny za zgodac swej rady.

Mówiąc o czasokresie trwania nowicjatu, należy zwrócić uwagę na fakt, że musiał on odbywać się $i$ to do ważności nie tylko rok ciąg1y, ale prawodawstwo wówczas obowiązujące nie dopuszczało żadnych przerw. Obliczanie czasu nowicjatu było tak d.okładne, że uwzględniano nie tylko dni, ale nawet i godziny. Jeśli ktoś na przykład został przyjęty do nowicjatu 10 sierpnia - godzinie 8 rano, to pierwszą profesję zakonna mógł złożyć dopiero 11 sierpnia roku następnego po godz. 8 rano.

Ponieważ jednak taka procedura obliczania czasu trwania nowicjatu byla nie tylko niewygodña, ale przyczyniala się do powstawania różnego rodzaju wątpliwości, dlatego w celu uniknięcia ich Kongregacja do Spraw Zakonnych dekretem Cum propositce z dnia $3 \mathrm{~V} 1914$ roku odstąpiła od matematycznego sposobu obliczania czasu trwania nowicjatu postanawiając, że w materii tej powinno się uwzględniać dni a nie godziny 24 .

Enchiridion de statibus perfectionis. Documenta Ecclesiae sodalibus constituendis, Romae 1949, s. $241-247$ (n. 241).

21 Normae secundum quas S. Congr. Episcoporum et Regularium procedere solet in approbandis novis institutis votorum simplicium (28 iunii 1901), T. Schaefer, De religiosis ad normam Iuris Canonici, ed. 4 Roma 1947, s. 1102-1135.

22 Tamże, n. 72.

23 Tamże, n. 75 .

24 AAS 6 (1914) 229; Fontes VI, n. 4419; Enchiridion de statibus perfectionis, s. $332-333$ (n. 281), n. 1: "Annus integer novitiatus, qui solus ad validitatem professionis requiritur, in posterum non stricte de 
$\mathrm{Na}$ podstawie tego samego dekretu Cum propositae postanowiono również, że nowicjat ulega przerwie i należy go rozpoczać od nowa w następujących wypadkach:

1) Usunięcia nowicjusza i opuszczenia przez niego po tym fakcie domu zakonnego.

2) Opuszczenia przez nowicjusza domu zakonnego bez pozwolenia przełożonego.

3) Przebywania poza domem nowicjackim ponad trzydzieści dni czy to ciaggyłch, czy z przerwami, choćby nawet za zgodą przelożonych zakonnych.

4) Jeśli pobyt nowicjusza poza nowicjatem nie przekroczył trzydziestu dni czy to ciagłych, czy z przerwami, to do ważności nowicjatu wystarczyło uzupełnienie dni opuszczonych 25.

\section{III}

Trzeba podkreślič fakt o wielkim znaczeniu, że Kodeks Prawa Kanonicznego z 1917 r., chociaż z odpowiednimi modyfikacjami, ale odnośnie do czasu trwania nowicjatu przyjąl zarządzenia dekretu Kongregacji dla Spraw Zakonnych z 3 V 1914 r..26 Kodeks ten nie tylko $\mathrm{w}$ całej rozciągłości podtrzymywał zasade dwunastomiesięcznego nowicjatu, ale rok ten musiał być ciągły (annum integrum et continuum) ${ }^{27}$. Czas zaś ciągły (tempus continuum) to według kan. 35 Kodeksu z 1917 r. taki okres, który nie dopuszcza żadnej przerwy (...continuum, quod nullam patitur interruptionem). Dłuższy czas nowicjatu, o którym mówił kan. $555 \S 2$ Kodeksu z 1917 r., o ile zostal wprowadzony przez konstytucje jakiegoś instytutu, nie był wymagany do ważności chyba że prawo własne stanowiło inaczej: „Jeżeli w konstytucjach nie powiedziano wyraźnie inaczej, to gdy przepisują one dla nowicjatu czas dłuższy, nie wymaga się go do ważności profesji" 28 .

hora ad horam, sed de die in diem intelligi debet. Idem dicendum de tribus integnis annis votorum simplicium, quae emissionem votorum solemnium praecedere debent".

25 Tamże, n. 2--3: „Novitiatus interrumpitur ita ut denuo incipiendus et perficiendus "sit: a) si novitius a superiore dimissus e domo exierit; b) si absque superioris licentia domum deseruerit; c) si ultra triginta dies etiam cum licentia Superioris extra novitiatus septa permanserit.

Si novitius infra triginta dies, etiam non continuos, cum superiorum licentia, extra domus septa permanserit, licet sub Superioris obedientira, requiritur ad validitatem, et satis est, dies hoc modo transactos supplere: at Supeniores hane licentiam nisi iusta et gravi de causa ne impertiant".

26 Por. kan. 555 i 556/1917.

27 Kan. 556 \& 1 - $2 / 1917$.

28 Kan. $555 \S 2 / 1917$. 
Jeśli zaś chodzi o nieobecność $w$ nowicjacie, to Kodeks $z$ 1917 r. ${ }^{29} \mathrm{w}$ porównaniu $\mathrm{z}$ dekretem z 3 V 1914 r. ${ }^{30}$ wprowadzil zמaczne złagodzenie dyscypliny. Dekret bowiem z 3 V 1914 r. postanawiał, że nieobecność $\mathrm{w}$ nowicjacie od pierwszego do trzydziestego dnia, i to pod sankcją nieważności nowicjatu, zawsze należało uzupełnić 31. Prawodawca polecił również przełożonym, by nie zwracali się oni o udzielenie dyspensy, jak tylko przy zaistnieniu ważnej i słusznej przyczyny 32. Kanon 556 \& 2 Kodeksu z 1917 r. postanawiał, że nowicjat nie ulegał przerwie, jeżeli nowicjusz przebywal poza domem nowicjatu do trzydziestu dni. Dopiero począwszy od dnia szesnastego zawsze należało uzupełnić wszystkie nieobecności w nowicjacie. Gdy jednak nowicjusz przebywal poza domem nowicjackim tylko do piętnastu dni, to stosownie do okoliczności i potrzeb - przełożeni mogli nakazać uzupełnienie brakujących dni, lecz zaniechanie tego nie wpływało na ważność nowicjatu ${ }^{33}$.

\section{IV}

Zupełnie inaczej natomiast rozstrzygnięto kwestie nieobecności w nowicjacie, jego przerwy oraz uzupełnienia brakujących dni $\mathrm{w}$ instrukcji Renovationis causam wydanej dnia 6 I 1969 r. przez Kongregacje Zakonów i Instytutów Swieckich ${ }^{34}$. Instrukcja postanowiła: „Do ważności nowicjatu potrzeba, aby trwał on 12 miesięcy" 35.

„Przebywanie poza wspólnotą i domem nowicjatu dłużej niż trzy miesiące, choćby $z$ przerwami, czyni nowicjat nieważnym. Jeśli nieobecność trwałaby krócej niż trzy miesiące, przełożeni wyżsi, po wysłuchaniu Mistrza nowicjuszy i rozpatrzeniu przyczyn nieobecności, w poszczególnych wypadkach powinni rozstrzygnąć, czy należy ten brak uzupełnić czy też nie. Jeżeli tak, nakażą przedłużenie i wyznaczą okres tego przedłużenia nowicjatu. Problem ten mogą rozstrzygnąc konstytucje" ${ }^{36}$.

Porównując wytyczne dotyczące czasu trwania nowicjatu, a szczególnie czasu nieobecności w nim, zamieszczone $\mathrm{w}$ Kodeksie

$20 \mathrm{Kan} .556$ \& $2 / 1917$.

30 Por̀. odnośnik 24.

si Tamże.

32 Tamże.

33 F. Baczkowicz, J. Baran, W. Stawinoga, Prawo Kanoniczne. Podręcznik dla duchowieństwa, t. I, wyd. III, Opole 1957, s. 687 .

s4 AAS 61 (1969) 103-120; P a we 1 VI, Charyzmat życia zakonnego. Przemówienia $i$ dokumenty, wybór i opracowanie A. z u c how ski, T. S u ì o w s k a, Poznań-Warszawa 1974, s. 264-282.

35 Tamże, n: 21.

so Tamże, n. 21-22. 
Prawa Kanonicznego z 1917 r. z instrukcją Renovationis causam z 6 I 1969 r., zauważamy następujące różnice:

1) Kodeks z 1917 r. polecał, by nowicjat - i to pod sankcją nieważności - trwał rok pełny (całkowity) i ciągły (per annum integrum et continuum) ${ }^{37}$. Instrukcja Renovationis causam natomiast opuszcza wyrażenie Kodeksu z 1917 r. zamieszczone w kan. $555 \S 1,2^{\circ}$ : per annum integrum et continuum, a mówi tylgo, że „do ważności nowicjatu potrzeba, aby trwal on 12 miesięcy" 38 .

2) Według kan. $556 \S 1$ Kodeksu Prawa Kanonicznego z $1917 \mathrm{r}$. nowicjat ulegał przerwaniu i trzeba go było rozpocząc od nowa, jeśli nowicjusz, chociażby nawet za pozwoleniem przełożonych, przebywal poza domem nowicjackim ponad trzydzieści dni czy to ciągłych, czy to $\mathrm{z}$ przerwami. Instrukcja Renovationis causam stwierdza zaś, że przerwanie nowicjatu następuje dopiero po trzymiesięcznej nieobecności w domu nowicjackim: „Przeby'wanie poza wspólnotą i domem nowicjatu dłużej niż trzy miesiące, choćby z przerwami, czyni nowicjat nieważnym" 39.

3) Według Kodeksu Prawa Kanonicznego z 1917 r. jeśli nowicjusz przebywał poza domem za pozwoleniem przełożonyeh albo przymusowo, pozostając $w$ zależności od owych przełożonych ponad dni piętnaście, lecz nie ponad trzydzieści, to do ważności nowicjatu wystarczyło tyilko uzupełnienie wszystkich dni od szesnastego do trzydziestego włącznie 40. Gdyby zaś nowicjusz przebywal poza domem nowicjatu nie ponad dni piętnaście, to przełożeni mogli, ale nie musieli nakazać, gdyż nie wpływa to na ważność nowicjatu, uzupełnienie nieobecności 41.

Instrulkcja Renovationis causam zniosła nakazany przez prawo obowiązek uzupełnienia opuszczonych dni nowicjatu. Sprawę tę pozostawiono do oceny przełożonych wyższych.

Trzeba podkreślić wielkiej wagi fakit, że przy podejmowaniu decyzji odnoszących się do uzupełniania nieobecności trwających krócej niż trzy miesiące przełożeni wyżsi powinni uwzględnić opinię mistrza nowicjatu i każdy wypadek oceniać indywidualnie. Problem uzupelnienia nowicjatu mogły rozstrzygać konstytucje 42.

Należy również zaznaczyć, że innowacja wprowadzona przez instrukcję Renovaticnis causam była $\mathrm{w}$ porównaniu $z$ wytycznymi

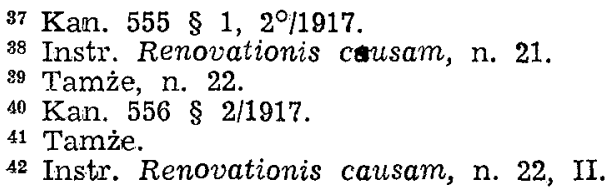


kan. 556 Kodeksu Prawa Kanonicznego z 1917 r. czymś zupełnie nowym, a nawet zbyt śmiałym posunięciem 43 .

\section{$\mathbf{V}$}

Kodeks Prawa Kanonicznego promulgowany przez papieża Jana Pawła II w 1983 r. w sprawie czasu trwania nowicjatu, jego przerw, nieważności oraz okresu działalności formującej zasadniczo przejął wytyczne poprzedniego ustawodawstwa, chociaz w wielu miejscach odstapił od nich. I tak kan. 648 \$ 1 Kodeksu z $1983 \mathrm{r}$, wzorując się na instrukcji Renovationis causam 44, znosi norme zamieszczoną w kan. $555 \S 1,2^{\circ}$ Kodeksu z 1917 r. wymagającą, by rok nowicjatu był calkowity i ciagly ${ }^{45}$. Kanon zaś $648 \S 1$ Kodeksu z 1983 r. mówi tyliko o dwunastu miesiącach: „Nowicjat do ważności powinien trwać dwanaście miesięcy spędzonych we wspólnocie nowicjatu...". Porównując cytowany powyżej kan. $648 \S 1$ Kodeksu z 1983 r. z kan. $555 \S 1,2^{\circ}$ Kodeksu z 1917 r. oraz instrukcją Renovationis causam n. 21, należy zauważyć, że Kodeks z 1983 r. mówi tylko o dwunastu miesiącach spędzonych we wspólnocie nowicjackiej, a więc znosi dawną normę o ciągłości fizycznej nowicjatu.

W celu dokładniejszego i lepszego zapoznania się z podobieństwami i różnicami zachodzącymi pomiędzy Kodeksem z 1917 r., instrukcją Renovationis causam oraz Kodeksem z 1983 r. w kwestii czasu trwania nowicjatu, przerwy oraz jego nieważności zostaną podane teksty odnośnych aktów prawnych.

\section{Kan. $556 \S 1-2 / 1917$}

„Przerywa się nowicjat tak, że należy go na nowo rozpocząć i odbyć, gdy nowicjusz... przebywal poza domem ponad dni trzydzieści ciągłych lub $z$ przerwami, z jakiegokolwiek powodu, nawet za zgoda przełożonych".

„Jeżeli nowicjusz, za zgodą przełożonych lub przymusowo przebywał poza domem $w$ zależności od przelożonego nie
Kan. $649 \S 1 / 1983$

„Z zachowaniem przepisu kan. $647 \S 3$ i kan. 648 \&2 nieobecność $w$ domu nowicjatu ponad trzy miesiące, czy to ciagła, czy przerywana, powoduje nieważność nowicjaru. Nieobecność przekraczająca piętnaście dni powinna być uzupełniona".

$43 \mathrm{I}$. Ting Pong I ee, De absentia a novitiatu, w: De institutione ad vitam religiosam ducendam iuxta instructionem Renorationis causam, Roma 1969, s. 121.

44 Por. Instr. Renovationis causam, n. 21.

45 Por. sitr. 119 niniejszego antylkulu. 
ponad trzydzieści dni $z$ przerwami, lecz ponad piętnascie, wymaga się i wystarcza do waiżności uzupełnić dni $w$ ten sposób spędzone; jeżeli nie było ani piętnastu, uzupelnienie może być przez przełożonych nakazane, ale do wazności nie jest konieczne".

Instr. Renovationis causam n. 22. I. II

„Przebywanie poza wspólnota i domem nowicjatu dłużej niż trzy miesiące, choćby $z$ przerwami, czyni nowicjat nieważnym. Jeżeli nieobecność trwałaby krócej niż trzy miesiące, Przelożeni wyżsi, po wysłuchaniu Mistrza nowicjuszy i rozpatrzeniu przyczyn nieobecności, $w$ poszczególnych wypadkach powinni rozstrzygnąc, czy należy ten brak uzupełnić czy też nie. Jeżeli tak, nakażą przedłużenie nowicjatu i wyznacza okres tego przedłużenia. Problem ten mogą rozstrzygnąć konstytucje".

Różnice pomiędzy kan. $556 \S 2$ Kodeksu z 1917 r., instrukcją Renovationis causam oraz kan. 648 i 649 Kodeksu z 1983 r. dadzą się sprowadzić do następujących kwestii:

1) Według kan. 556 § 2 Kodeksu z 1917 r. nieobecność trwająca ponad trzydzieści dni zawsze powodowała nieważność nowicjatu, nieobecność zaś do piętnastu dni można było nakazać uzupełnić, ale nie było to konieczne.

2) Wedlug instrukcji Renovationis causam nowicjat ulegał przerwie dopiero wówczas, gdy przebywanie poza wspólnota nowicjacką przekraczało trzy miesiące, a nieobecność do trzech miesięcy mogła, ale nie musiała być uzupełniona.

Zgodnie z zasadami zawartymi w instrukcji Renovationis causam zlożenie pierwszych ślubów zakonnych mogło nastąpić po dziewięciomiesięcznym pobycie w nowicjacie. 
3) Kodeks z 1983 r. wybrał drogę pośrednią i tylko częściowo przejął normy instrukcji Renovationis causam. W kanonie 649 $\S 1$ postanowiono, że nieobecność przekraczająca piętnaście dni zawsze musi być uzupełniona, a przekraczająca trzy miesiące powoduje nieważność nowicjatu.

Jakimi motywami kierował się najwyższy prawodawca kościelny przy rezygnacji $z$ niektórych wytycznych instrukcji Renovationis causam? Wydaje się, że powody były następujące:

1) Instrukcja Renovationis causam została wydana tylko dla celów eksperymentalnych 46 .

2) Praktyka poszła tak daleko, że z błahych powodów skracano nowicjat do dziewięciu miesięcy.

Można zapytać również, co bylo powodem, iż zarówno instrukcja Renovationis causam 47, jak i Kodeks Prawa Kanonicznego z 1983 r.48 nie mówią już, że nowicjat do ważności powinien trwać „przez cały rok bez przerwy" 49, ale stwierdzaja tylko: "Nowicjat do ważności powinien trwać dwanaśce miesięcy..." 50. Odpowiadając na powyższe pytanie, trzeba stwierdzić, że odstąpienie od dawnego sposobu obliczania czasu trwania nowicjatu podyktowane zostało wprowadzeniem tzw. okresów działalności formujących 51, zwanych obecnie okresami praktyki apostolskiej $\boldsymbol{5}_{\mathbf{2}}$. Skoro zaś zarówno instrukcja Renovationis causam, jak i Kodeks Prawa Kanonicznego z 1983 r. pozwoliły na wprowadzenie jednego lub nawet więcej okresów praktyki apostolskiej podejmowanej poza wspólnotą nowicjacką ${ }^{53}$, to było rzeczą oczywistą, że musiano zrezygnować $z$ dawnego sposobu obliczania czasu trwania nowicjatu.

46 Instr. Renovationis causam, Wprowadzenie $w$ życie norm szczególowych, VII; „Normy te, wydane dla celów eksperymentalnych...".

47 N. 21.

48 Kan. 648 \& $1 / 1983$.

49 Kan. $555 \& 1,2^{\circ} / 1917$.

$50 \mathrm{Kan} .648 \S 1 / 1983$; Instr. Renovationis causam, n. 21.

51 Instr. Renovationis causam, n. 23-25: „Kapituła generalna większością przynajmniej dwóch trzecich głosów może zdecydować o wprowadzeniu, tytulem eksperymentu, jednego lub kilku okresów działalności formującej $w$ zakresie prac, zgodnych $z$ charakterem instytutu, dla dopemienia przygotowania nowicjuszów... Cały czas trwania działalności formującej nowicjuszy poza domem nowicjatu należy doliczyć do 12 miesięcy koniecznych, zgodnie $z$ numerem 21 do ważności nowicjatu, tak jednak, by przedłużony nowicjat nie trwał dłużej niż dwa lata... Charakter takiej dzialalności formującej, odbywanej poza domem nowicjatu, może być różny, zależnie od celu Instytutu i rodzaju jego dziel..."; A. Diez, De activitate apostolica, w: De institutione ad vitam religiosam ducendam, s. 131.

52 Kan. $648 \quad \S 2 / 1983$.

${ }^{53}$ Instr. Renovationis causam, n. 23-25; Kan. $648 \S 2 / 1983$; Definicje "okresów praktyki apostolskiej" podaje D. J. Andres, Il diritto dei religiosi. Commento al Codice. Versione della seconda edizione spagno- 
Należy podkreślić, że prawodawca kościelny nie nakazuje wprowadzania praktyk apostolskich, ale tylko na nie pozwala. Najwyższa władza instytutu zakonnego, a jest nią kapituła generalna, może się na owe praktylki zgodzić lub tė̇ nie, ale skoro się na nie zdecyduje, wówczas trzeba to jasno sprecyzować i przepis ów, po zatwierdzeniu przez odpowiedni organ, zamieścić w konstytucjach 54. Jeśli zaś nawet $w$ jakimś instytucie zakonnym zostaly wprowadzone praktyki apostolskie, to nowicjat nie może trwać dłużej niż dwa lata. Wniosek powyższy wynika z kan. $648 \S 3$, gdzie czytamy: „Nowicjatu nie należy przedłużać ponad dwa lata". A zatem, gdyby w jakimś instytucie zakonnym nowicjat lacznie $z$ praktykami apostolskimi byl dwuletni, to $w \dot{z} a-$ den sposób nie ma tu zastosowania kan. $653 \S 2$, który mówi: „Jeśli po upływie nowicjatu uznano nowicjusza za zdatnego, należy go dopuścić do czasowej profesji, w przecimnym razie wydalić. Jeżeli zaś co do jego zdatności istnieje wątpliwość, przełożony wyższy może przedłużyć okres próby,.zgodnie $z$ własnym prawem, nigdy jednak ponad sześć miesięcy".

$\mathrm{Na}$ przedłużenie nowicjatu ponad dwa lata zawsze trzeba uzyskać pozwolenie od Stolicy Apostolskiej 55. Nie można bowiem wobec kan. 648 \& 3 Kodeksu z 1983 r. stosować wykładni rozszerzającej, gdyz jest to sprzeczne $z$ kan. 18, który stwierdza: „Ustawy, które ustanawiają kary, ograniczają swobodne wykonywanie uprawnień albo zawierają wyjątek od ustawy, podlegają scisłej interpretacji".

\section{VI}

Chociaż Kodeks Prawa Kanonicznego z 1983 r., o czym już wyżej była mowa, wymaga do ważności nowicjatu dwunastu miesięcy 56, to jednak pozwala on na przyspieszenie pierwszej profesji, ale tylko o piętnaście dni: „Za zezwoleniem kompetentnego przełożonego wyższego pierwsza profesja może być antycypowana, ale nie ponad piętnaście dni" (kan. 649 § 2).

Z zacytowanego wyżej kanonu wynika, że na zasadzie wyjątku

la, Roma 1984, s. 246: „Detta esercitazione apostolica si può definire come l'insieme di azioni apostoliche, coerenti con la indole del IVCR, che i novizi sotto la moderazione del maestro, mettono in pratica durante il noviziato, però fuori della comunità del medesimo, ordinate al perfezionamento della loro formazione".

54 Kan. 648 \& $2 / 1983$.

55 J. J. Andres, s. 249; "Trattandosi di un precetto universale, per prorogare regolarmente il biennio e necessamia la licenza della Santa Sede, ragionarta e sollecitata con sufficiente peso ed antecipo. Se sia stata accordaita ad un Istituto nellie sue Costituzioni, nulla può obiettarsi in contrario".

${ }_{56} \mathrm{Kan} .648 \S 1 / 1983$. 
nowicjat może trwać tylko jedenaście i pół miesiąca. Jednak prawo wlasne (konstytucje) pod żadnym warunkiem na mocy kan. $649 \S 2$ Kodeksu z 1983 r. nie może wprowadzić ogólnej reguły, by wszyscy nowicjusze składali pierwsze sluby zakonne po jedenasto i półmiesięcznym pobycie $w$ nowicjacie, gdyz przepis kan. 649 § 2 stanowi wyjątek od ogólnej zasady zawartej w kan. $648 \S 1$, a wyjątku nie wolno utożsamiać $z$ normą.

Przełożony wyższy, a jest nim z zasady ten, który przyjmuje do nowicjatu, może pozwolić na przyspieszenie pierwszych sllubów nie tylko pojedynczemu nowicjuszowi, ale nawet i całej grupie. Twierdzenie powyższe znajduje swoje uzasadnienie w jednej z reguł prawnych, która brzmi: „Gdzie prawo nie rozróżnia, i my nie po:winniśmy rozróżniać - ubi lex non distinguit, nec nostrum est distinguere" 57. Skoro zatem prawodawca używa ogólnego sformułowania mówiąc: „Za pozwoleniem kompetentnego przełożonego wyższego pierwsza profesja może być antycypowana, ale nie ponad piętnascie dni" 58 , to zgodnie $z$ wyżej przytoczona zasada prawna nie ma podstaw do zastosowania interpretacji ścieśniającej.

Można również postawić pytanie: Dlaczego Kodeks z 1983 r. w kan. 649 \& 2 pozwala na przyspieszenie pierwszej profesji o piętnaćcie dni? Ponieważ kan. 649 $§ 1$ nie nakazuje pod żadną sankcją uzupełnienia nieobecności w nowicjacie trwającej piętnaście dni, to konsekwentnie pozwolono również na przyspieszenie o tyleż dni pierwszej profesji zakonnej.

W celu wyczerpania problemu dotyczącego przyspieszenia pierwszych ślubów i braku konieczności uzupełnienia nowicjatu $w$ wypadku przebywania poza nim do piętnastu dni, należałoby jeszcze postawić następujące pytanie: Czy istnieje możliwość opuszczenia piętnastu dni nowicjatu $z$ jednoczesnym przyspieszeniem pierwszej profesji o tyleż samo dni?

$\mathrm{Na}$ przedłożoną powyżej kwestię odpowiedź musi być zdecydowanie negatywna, gdyz:

1) Kanon 649 § 1 Kodeksu z 1983 r. wyraźnie stwierdza: „Nieobecność przekraczająca piętnaście dni powinna być uzupelniona".

2) Gdyby dokonano kumulacji, czyli oprócz przebywania poza domem nowicjackim przez piętnaście dni zarazem przyspieszono profesję również o piętnaście dni, to wówczas nieobecność wynosilabty dni trzydzieści, a kanon $649 \S 1$ mówi tylko o piętnam stodniowej nieobecności.

3) Nie można w przedstawionej kwestii stosować wyładni roz-

57 L. De Ma uri, Regulae iuris. Raccolta di 2000 regole del diritto, ed. 11. Milano 1976, s. 136; D. J. Andres, s. 254.

os Kan. 649 \& $2 / 1983$. 
szerzającej, co, jak zaznacza A. Gutierrez, czynią niektórzy mistrzowie nowicjatu 59 , gdyż nie tylko nie pozwalają na to zasady odnoszące się do interpretacji ustaw kościelnych 60 , ale jest to również działanie contra intentionem legislatoris 61.

Trzeba podkreślić, że chociaż w przypadku piętnastodniowego pobytu poza wspólnotą nowicjacką $z$ równoczesnym przyśpieszeniem pierwszej profesji o piętnaście dni śluby zakonne będą ważne, to jednak stają się one niegodziwe. Twierdzenie powyższe można uzasadnić przepisem kan. 649 § 1, który brzmi: ,...nieobecność w domu nowicjatu ponad trzy miesiące, czy to ciągla, czy przerywana, powoduje nieważność nowicjatu". A zatem skoro dopiero nieobecność przekraczająca trzy miesiące czyni nowicjat nieważnym, to a contrario nieobecność wynoszaca nawet trzydzieści dni nie wpływa na ważność pierwszych ślubów 62.

\section{VII}

Z przeprowadzonego badania dotyczącego czasu trwania nowicjatu wynika, że $\mathrm{w}$ historii instytutów życia zakonnego instytucja ta podlegala wielorakim ewolucjom.

W artylkule wykazano, że $w$ początkach istnienia różnych form zorganizowanego życia zakonnego nie bylo jednolitych przepisów normujących czas trwania nowicjatu, ale każdorazowo zależało to od wytycznych poszczególnych zakonodawców albo nawet od przełożonego przyjmującego kandydata do instytutu. Jednak w miarę ksztaltowania się poszczególnych instytucji zakonnych (nowicjat, sposób przyjmowania, profesja itp.), stosowanej praktyki, zaistniałych okoliczności, zarządzeń zarówno władzy kościelnej, jak i świeckiej, kwestię te stopniowo ujednolicano oraz poddawano różnorakim eksperymentom.

$\mathrm{W}$ opracowaniu $\mathrm{W}$ szczególny sposób zwrócono uwagę na czas trwania nowicjatu w Kodeksie Prawa Kanonicznego z 1917 r., instrukcji Renovationis causam oraz Kodeksie Prawa Kanonicznego z $1983 \mathrm{r}$. Przy omawianiu tego problemu w świetle wymienionych wyżej aktów prawnych przeprowadzono analize poszczególnych zarządzeń oraz podano uzasadnienie zmian $w$ nich dokonywanych.

\section{De tempore durationis novitiatus}

In hoc articulo monstratur in historia institutorum vitae religiosae spatium novitiatus durandi multimodis mutatum fuisse.

59 A. Gutierrez, De duratione novitiatus, Commentarium pro religiosis et missionaniis 67 (1986) 151.

60 Kan. 18/1983.

61 A. Gutierrez, s. 152.

e2 Tamże, s. 153-154. 
Peculiari modo pertractatae sunt eae normae legis, quae ad hanc qaestionem pertinent quaeque in Codice Iuris Canonici anno 19:17 promulgato, instructione Renovationis causam die 6 mensis ianuarii 1969 a Congregatione pro Religiosis et Institutis Saecularibus typis expressa necnon in Codice Iuris Canonici anno 1983 promulgato inveniuntur.

In nostra disceptatione etiam analisis normarum, quae in supralaudatis actis editae sunt peragitur atque nonnullae quarestiones agituntur, quae ex operis nostri proposito oriuntur. 